\title{
Assessing and allocating beds in acute medicine in east London
}

\author{
DUNCAN W VERE
}

As a consequence of the Resource Allocation Working Party ${ }^{1}$ and of the government's general financial policies for the National Health Service ${ }^{2}$ it is proposed to cut funds to hospitals in east London. Part of the discussion on these cuts has centred on general medical beds classified as "acute." The draft plan is to cut acute beds according to arbitrary norms, and this is partly justified on the grounds that:

(i) existing bed provision for acute medicine is believed to be broadly sufficient;

(ii) need cannot be measured and is always outstripped by demand; and

(iii) the mean length of stay in medical beds has fallen progressively and the rate of turnover increased over the past 15 years, a trend that, it is argued, can and must continue.

The proposed policy is that these beds be cut, that patient throughput be increased, and that we can and should aim to keep case numbers per year approximately as now. The cuts proposed by the North East Thames Regional Health Authority are based on a norm for all local acute beds of three per 1000 now, falling to two per 1000 by 1991, albeit for an increased "planning population." The calculated impact would be a cut in total acute bed numbers from 680 to 450 in Tower Hamlets Health District. The district is likely to resist these proposals in part, though accepting considerable cuts to balance finance.

We have begun to investigate these proposals by surveying all acute general medical work in the London Hospital (Mile End and Whitechapel) from January to mid-April 1983. As acute medical work at Bethnal Green and Mildmay Mission hospitals has now stopped this represents all the acute hospital medicine in Tower Hamlets Health District. The survey was made by registrars responsible for acute admissions, and from data kindly supplied by the Emergency Bed Service. We have also studied case numbers and lengths of stay of our own firm's admissions for evenly spaced years from 1969 to 1982 . Our firm represents roughly a one in five unbiased sample of the acute intake at Whitechapel. Also, when on duty, our registrar has referee responsibilities across the district. The number of beds allocated to our firm varied between 15 and 18 over the period, but the number of occupied beds bore little relation to these nominal totals.

\section{Survey findings}

Our findings include the following:

(a) The official figures for acute beds are all based on patients who enter hospital; they ignore any who are deemed to need admission but who have to be sent away because beds are full. It is therefore true that need cannot be measured, but not perhaps in the sense in which most might intend.

(b) In these winter months 21 patients deemed to require

Department of Pharmacology and Therapeutics, The London Hospital Medical College, London E1 2AD

DUNCAN W VERE, MD, FRCP, professor of therapeutics admission were sent out of the district; and 63 suffered a summary postponement of admission, a process associated with some hazard and distress. Male and female bed places were closed to admissions via the Emergency Bed Service, but not to patients arriving by ambulance, for roughly one half of all days.

(c) The lengths of stay of patients admitted to our firm are shown in table I. The distribution is clearly one for which the mean is not an appropriate measure; medians give different results (10 and eight days, against 14 and $12 \cdot 8$ for the respective means for the years 1969 and 1982).

(d) The effects of weekends on discharges for shorter lengths of stay were apparent, especially for 1969. This effect became progressively less clear in succeeding years.

(e) The lengths of stay were divided into bands of five days; the $\chi^{2}$ test for independent categories (Pearson's test) showed no significant differences for any time band except the last (table I),

TABLE I-Lengths of stay of acute medical patients. (Figures are numbers (\%) of admissions; the third figure for each year is the $\chi^{2}$ value)

\begin{tabular}{|c|c|c|c|c|c|}
\hline $\begin{array}{l}\text { Length of stay } \\
\text { (days) }\end{array}$ & $1969-70$ & 1974 & 1978 & 1982 & Sum of $\chi^{2}$ \\
\hline $1-5$ & $62(25 \cdot 5)$ & $53(24 \cdot 8)$ & $60(26 \cdot 8)$ & $115(36 \cdot 6)$ & \\
\hline $6-10$ & $\begin{array}{c}1 \cdot 10 \\
66(27 \cdot 2)\end{array}$ & $\begin{array}{c}1 \cdot 41 \\
53(24 \cdot 8)\end{array}$ & $\begin{array}{c}0.43 \\
50(22 \cdot 3)\end{array}$ & $\begin{array}{c}6.03^{*} \\
66(21.0)\end{array}$ & 8.96 \\
\hline & 1.29 & 0.12 & $0 \cdot 16$ & 0.90 & $2 \cdot 47$ \\
\hline $11-15$ & $45(18.5)$ & $36(16 \cdot 8)$ & $45(20 \cdot 1)$ & $59(18 \cdot 8)$ & \\
\hline & 0.0007 & 0.36 & 0.27 & 0.007 & 0.64 \\
\hline $16-20$ & $25(10 \cdot 3)$ & $25(11 \cdot 7)$ & $30(13.4)$ & $28(8.9)$ & 260 \\
\hline $21-25$ & $21 \quad(8 \cdot 6)$ & $10(4 \cdot 7)$ & $4(1.8)$ & $14(4.5)$ & 202 \\
\hline $26-30$ & $\begin{array}{l}6 \cdot 82^{* * *} \\
9 \\
(3 \cdot 7)\end{array}$ & 0.03 & $\begin{array}{l}4 \cdot 48^{*} \\
(5 \cdot 8)\end{array}$ & 0.14 & $11 \cdot 47$ \\
\hline $20-30$ & $0 \cdot 28$ & $1 \cdot 11$ & 0.97 & 1.09 & 3.02 \\
\hline $31-35$ & $5(2 \cdot 1)$ & $3(1 \cdot 4)$ & $3(1 \cdot 3)$ & $12(3 \cdot 8)$ & 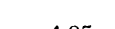 \\
\hline$\geqslant 36$ & $10(4 \cdot 1)$ & $22(10 \cdot 3)$ & $19(8.5)$ & $10(3 \cdot 2)$ & 4.85 \\
\hline & 1.61 & $6.01^{*}$ & 2.02 & $4.44^{*}$ & $14 \cdot 09^{*}$ \\
\hline \multirow{4}{*}{$\begin{array}{l}\text { Total No of } \\
\text { patients } \\
\text { Mean length of } \\
\text { stay (days) } \\
\text { Median length of } \\
\text { stay (days) }\end{array}$} & 243 & 214 & 224 & 314 & 995 \\
\hline & & 16.32 & 15. & 12.8 & \\
\hline & 14 & 16.34 & $15 \cdot 4$ & $12 \cdot 8$ & \\
\hline & 10 & 11 & 11 & 8 & \\
\hline
\end{tabular}

Significant findings: ${ }^{*} \mathrm{p}<0.05 ;{ }^{* *} \mathrm{p}<0.01$.

showing that the fall in mean length of stay did not reflect a change in practice for most of the patients. Tests for individual table cells, however, showed that there was only one that reached significance for a large group of patients-namely, more than 25 . That for one to five days was significant for the year $1982\left(\chi^{2}=\right.$ $6.03,0.05<\mathrm{p}<0.01, \mathrm{df}=1)$. Inspection of the data for one to five days soon showed the cause of the difference; there were 38 cases of overdose in this category in 1983 compared with 10 in 1969 (table II). Most of the admissions in the up to five day class were social casualties, such as patients who had poisoned themselves or were suffering from alcoholic bouts and patients who discharged themselves. So the fall in mean length of stay was not in the main attributable to some imagined increase in efficiency by the firm but to a small relative rise in very short admissions, though there was a much smaller relative fall in length of stay of patients who stayed over 20 days. Though this reached significance in four instances, this effect was not sustained, nor was it consistent in direction.

continued on page 850 


\section{Government wants action on competitive tendering for NHS's support services}

The Secretary of State for Social Services, $\mathrm{Mr}$ Norman Fowler, has issued a circular to the National Health Service (HC(83)18) calling on health authorities to put cleaning, catering, and laundry services out to competitive tender. Private contractors will be invited to tender against the existing NHS in house services, and the work will go to whoever provides the lowest tender.

"Cleaning, catering, laundry, and linen services in the NHS in England cost almost $£ 900$ million a year," declared Mr Fowler. "I am confident that worthwhile savings will result from competitive tendering for those services. The benefits of all savings will be available for patient care within each authority's own area so that the authorities and the patients they serve have a very direct interest in the success of this initiative. The deciding factor will be: who can provide the most economic service to clearly defined requirements? If the in house service can do so then they will continue to provide it. But if a private contractor can do as good a job more economically then it is only common sense to hire him."

$\mathrm{Mr}$ Fowler and his colleagues have met representatives of the cleaning, catering, and laundry industries. "The industries are," he said, "in no doubt of the high standards expected of them if they are to win hospital contracts. No doubt they will win some and lose others in competition with hospitals' own services. What is important in the public interest is that costs should be tested and savings maximised."

The government wants early progress on competitive tendering, and the circular asks authorities to submit their programmes to regional health authorities by the end of February 1984.

\section{Policy on use of the private sector}

Explaining the government's policy on the use of the private sector the circular states:

- “The government's expenditure plans envisage that improvements in patient services will in part depend on getting better value for money out of available resources. This applies, of course, to all aspects of the NHS, but the scope for savings in hospital support services is potentially high, and authorities need to be wholly satisfied and to demonstrate that those services are provided as efficiently and economically as possible.
- "The government believes that the use of private contractors, under carefully drawn and properly controlled contracts, can often prove the most cost effective way of providing support services. Value added tax has until now been imposed on work put out to contract but not on in house services. The government is making arrangements for this value added tax to be refunded to health authorities from 1 September 1983. The way is now clear, therefore, for private contractors to compete on a fairer basis with in house services. This circular concentrates on domestic, catering, and laundry services.

"Ministers welcome the initiative taken by some health authorities who have recently gone to tender and contract for support services. They wish to see this initiative taken up by health authorities generally. Authorities should ensure that, in doing so, proper comparisons are made taking into account all relevant factors and that support service management and staff interests are kept informed. If such a comparison shows that the in house service is less economic that service should be contracted out. Decisions on contracting out should be reached openly, and those likely to be affected need to be assured that the comparisons upon which they are based have been made objectively. It should be made clear to all that the benefits of savings achieved will be available for patient care within the authority's own area."
Talking Point-continued from page 849

TABLE II-Self administered overdoses as a percentage of all admissions

\begin{tabular}{lcc}
\hline Year & $\begin{array}{c}\text { "', of all } \\
\text { admissions }\end{array}$ & $\begin{array}{c}\text { "', of patients } \\
\text { admitted for } 1 \text { to } 5 \text { days }\end{array}$ \\
\hline $1969-70$ & $6 \cdot 2$ & $16 \cdot 0$ \\
1974 & $7 \cdot 5$ & $22 \cdot 6$ \\
1978 & $6 \cdot 7$ & $23 \cdot 3$ \\
1983 & $12 \cdot 4$ & $32 \cdot 2$
\end{tabular}

\section{Misconceived interpretation}

The suggestion that further cuts in acute beds would merely continue an existing trend is largely a naive and misconceived interpretation. A real fall in lengths of stay would be possible only if the numbers of social casualties were to rise, such as patients suffering from overdosage, and the numbers of longer stay patients needing care to fall, or for the weekend to disappear. These are scarcely desirable possibilities, and in any case are beyond medical reach, though they would no doubt make NHS hospitals more cost effective by the administrative criteria now accepted. It may be that other forms of acute care-for example, surgery-have cut the lengths of stay in real terms, but this cannot justify a cut in acute medical beds if recuperation cannot be hastened without detriment to patients.

We believe that much may be learnt from these simple studies. The methods used by the administration to assess provision of hospital facilities in acute medicine are grossly inadequate, providing no more than a superficial impression of the real state of affairs in acute medicine. They seem likely to lead to important underprovision. That the conclusions drawn from such figures may in fact hold for all acute beds is not denied, though it is doubted. It certainly does not hold for acute medicine, and may not hold for other sectors within the "total acute" category.

Several important questions emerge once the "total acute" bed category is subdivided. There are compelling reasons to look at emergency medicine and surgery differently from other acute specialties because their work is different. Acutely ill patients admitted as emergencies require urgent care. They also form an important proportion of those patients seen by medical students during their training. Furthermore, within the "total acute" category there are specialties that merit recognition as regional specialties-specialties whose cost has risen dramatically with their clinical success, but which now rob the Peter of the district's acute budget to pay the Paul of high technology medicine without attracting regional funds. Such specialties double the impact of RAWP: inner London teaching districts lose money to cover regional inequalities in general acute provision and lose it again to pay for unrecognised, but heavily used, regional specialties that are not yet recognised as such. Acute general medicine is a vital aspect of hospital care. It is the "shop window" of the hospital service because when someone falls acutely, seriously, and unexpectedly ill, failure of the service through delays - in casualty, lodging beds, long ambulance journeys, and postponed admission-has a disastrous effect on morale, both among the public and within the service itself.

The "improved efficiencies" demanded by health authorities are entirely right if they can be met by removing waste but quite wrong if met by damaging the care of patients. Spurious statistics are dangerous if they are used unwittingly to justify cuts in care or patterns of resource distribution that do not relate to clinical needs. No reliable decisions about future provision can be made unless health authorities adopt valid statistical procedures and cease turning a blind eye to measures of need.

\section{References}

1 Department of Health and Social Security. Sharing resources for health in England: report of the resource allocation working party. London: HMSO, 1976.

2 Anonymous. Revised revenue cash limits for England 1983-4. Br Med 7 1983;287:374.

Anonymous, Spending on health. $6300 \mathrm{~m}$ more than planned in 1983-4. Br Med f 1983;287:235.

(Accpted 18 August 1983)

Published by the Proprietors, THE BRITISH MEDICAL ASSOCIATION. Tavistock Square, London WC1H 9JR, and printed in Great Britain by George Pulman and Sons Limited of London and Bletchley, Typesetting by Bedford Typesetters Limited, Bedford.

Registered as a Newspaper 